\title{
Re-imagining the kitchen as a site of memory
}

\section{Angela Meah \& Peter Jackson}

To cite this article: Angela Meah \& Peter Jackson (2015): Re-imagining the kitchen as a site of memory, Social \& Cultural Geography, DOI: 10.1080/14649365.2015.1089587

To link to this article: http://dx.doi.org/10.1080/14649365.2015.1089587

\section{(c) 2015 The Author(s). Published by Taylor \& Francis}

\section{Published online: 29 Sep 2015.}

\section{Submit your article to this journal $\llbracket$}

\section{Џ Article views: 216}

Q View related articles $\square$

View Crossmark data ¿ 


\title{
Re-imagining the kitchen as a site of memory
}

\author{
Angela Meah and Peter Jackson \\ Department of Geography, University of Sheffield, Sheffield, UK
}

\begin{abstract}
Extending the focus of previous geographical research on public spaces of remembering, this paper demonstrates the ways in which memory work also takes place in private domestic spaces. The paper draws on a combination of life history and ethnographic research undertaken in Northern England, examining kitchens as a specific lieu de mémoire, showing how they serve as places where valued items are displayed and material artefacts are curated as part of the construction and reproduction of personal memories and familial identities. Using ethnographic and visual evidence from two case study households, the paper demonstrates the role of material artefacts in curating the past and materialising memory. Additionally, life history interviews with older women reveal narratives of everyday cooking practices which seemingly contradict popular discourses of the past, questioning conventional ideas about the distorted nature of nostalgia. In combination, our data represent complex narratives in which the past can be seen as infusing the present, and where present-day concerns are revealed as actively shaping public discourses which favour a return to an idealised past, which may have little bearing on people's actual lived experience.
\end{abstract}

\section{Ré-imaginer la cuisine en tant que site de mémoire}

\section{RÉSUMÉ}

Elargissant le domaine des recherches géographiques précédentes sur les lieux publics de mémoire, cet article démontre comment le travail de mémoire a aussi lieu dans les espaces domestiques privés. L'article exploite un ensemble d'histoires de vies et de recherches ethnographiques menées au Nord de l'Angleterre et examine des cuisines en tant que lieu de mémoire spécifique tout en montrant comment elles servent de lieux où des objets appréciés ont été exposés et des objets anciens conservés, dans le cadre de la construction et de la reproduction de souvenirs personnels et d'identités familiales. Utilisant des preuves ethnographiques et visuelles d'études de cas de deux foyers, l'article démontre le rôle d'objets matériels dans la conservation du passé et la matérialisation de la mémoire. De plus, des entretiens sur des histoires de vie avec des femmes plus âgées révèlent des récits de pratiques culinaires quotidiennes qui contredisent apparemment les discours populaires

\section{ARTICLE HISTORY}

Received 19 February 2015

Accepted 22 July 2015

\section{KEYWORDS}

Kitchens; sites of memory; ethnography; nostalgia; UK

\section{MOTS CLÉS}

Cuisines; sites de mémoire; ethnographie; nostalgie; Royaume-Uni

\section{PALABRAS CLAVE}

Cocinas; lugares de la memoria; etnografía; nostalgia; Reino Unido

CONTACT Angela Meah a.meah@sheffield.ac.uk

(c) 2015 The Author(s). Published by Taylor \& Francis.

This is an Open Access article distributed under the terms of the Creative Commons Attribution License (http://creativecommons.org/ Licenses/by/4.0/), which permits unrestricted use, distribution, and reproduction in any medium, provided the original work is properly cited. 
du passé, remettant en question des idées conventionnelles au sujet de la nature faussée de la nostalgie. Dans l'ensemble, nos données représentent des récits complexes à travers lesquels le passé peut être vu comme imprégnant le présent, et où les problèmes de notre époque se révèlent être des principes activement formateurs de discours publics en faveur d'un retour à un passé idéalisé, qui n'a peut-être que très peu en commun avec la véritable expérience vécue des personnes.

\section{Re-imaginar la cocina como lugar de memoria}

\section{RESUMEN}

Ampliando el campo de investigación geográfica previa en espacios públicos de recuerdo, este trabajo demuestra la forma en que el trabajo de memoria también se lleva a cabo en espacios privados domésticos. El documento se basa en una combinación de historia de vida e investigación etnográfica realizada en el norte de Inglaterra, examinando la cocina como lieu de mémoire específico, mostrando cómo sirven como lugares donde se muestran elementos valorados y se conservan objetos materiales como parte de la construcción y reproducción de recuerdos personales e identidades familiares. Utilizando evidencia etnográfica y visual de dos casas tomadas como de estudio de caso, el documento demuestra el papel de objetos materiales en la exposición del pasado y la materialización de la memoria. Además, las entrevistas de historia de vida a mujeres mayores revelan relatos de prácticas de cocina de todos los días, que aparentemente contradicen los discursos populares del pasado, cuestionando las ideas convencionales sobre la naturaleza distorsionada de la nostalgia. En combinación, nuestros datos representan narrativas complejas en las que el pasado puede ser visto como infundiendo al presente, y donde las preocupaciones de hoy en día se revelan dando activamente forma a los discursos públicos que favorecen el retorno a un pasado idealizado, que pueden tener poco que ver con la experiencia vivida real de la gente.

\section{Introduction}

We began writing this paper during the week that marked both the seventieth anniversary of the liberation of Auschwitz and the fiftieth anniversary of Winston Churchill's funeral moments in time which were both commemorated via high-profile public events: the former at Auschwitz and across the world, the latter through a retracing of the route by the vessel which carried Churchill's coffin. These events - both of which were enacted at specific sites are a reminder of the extent to which we live in an age in which public acts of remembering - or at least not forgetting - have seemingly become ubiquitous (cf. Huyssen, 2003). That space is central to understanding the processes and practices implicated in remembering is reflected in the significant contribution that geographers have made to the burgeoning literature on memory in recent years (as reviewed by Legg, 2007). Much of this work has been concerned with public spaces and collective or social memory, not uncommonly associated with war (Heffernan, 1995; Johnson, 1999; Muzaini, 2013), violence and tragedy (Foote, 2003; Sarmento, 2009; Tyner, Alvarez, \& Colucci, 2012) and national monuments, heritage sites and museums. ${ }^{1}$ These all represent what Nora (1989) has referred to as lieux de mémoire - places of memory - which, in the modern period, are specific places where 
memory, both formal and popular, is produced and negotiated (Sarmento, 2009); where it crystallises and secretes itself, enabling individuals to block the work of forgetting (Nora, 1989, p. 7). Memory, suggests Nora, is attached both to physical sites, such as burial places, battlefields and prisons, which embody tangible notions of the past, as well as to celebrations, spectacles and rituals that retain an aura of the past (Hoelscher \& Alderman, 2004) or forge a connection with previous events. ${ }^{2}$

That politics is implicated in public acts of remembering has been highlighted by those scholars who have drawn attention to how particular places, people and events are both constructed and contested via officially sanctioned public displays of commemoration. ${ }^{3}$ Indeed, as Muzaini (2013, p. 392) observes, 'Remembering is often done in the service of objectives that ensure what of the past gets to remain in posterity or relegated to oblivion'. Put another way, memorials 'narrate history in selective and controlled ways, hiding as much as they reveal' (Dwyer \& Alderman, 2008, p. 168).

In contrast with public sites of memory where national identities are not uncommonly reinforced, much less has been written concerning how memory erupts (Atkinson, 2007) in ordinary, private, domestic spaces where, it can be argued, class and gender, ethnicity and family, may be more salient than national identities. Notable exceptions have been Datta's (2006) research on architecture, gender, class and the modernisation of Bethnal Green Estate, along with Bhatti and colleagues (2008), whose work on gardens highlights the haptic dimensions of memory, which 'reverberate' through mundane, routinised tasks such as cooking, cleaning and gardening, which may transport an individual to other times and other places through reverie. Private memories are often dismissed as nostalgic, betraying a partial, romanticised and erroneous view of the past, an idea which geographers such as Blunt (2003) and Legg (2004) have sought to challenge. In this paper, we aim to develop these ideas further, exploring how memories are mobilised in the private space of the domestic kitchen - and through one particular, seemingly mundane, everyday activity - cooking - which, when our participants reflect upon past practices during a narrative interview, transforms kitchens and the artefacts found within them into sites of memory. This paper foregrounds the situatedness of the kitchen within the complex, temporal topography of domestic life, revealing how it can become a repository for, and representative of, 'memory and nostalgia for the past, everyday life in the present, and future dreams and fears' (Blunt \& Varley, 2004, p. 3). As Hutcheon (1998) points out, nostalgia is inextricably bound up with notions of 'home', with its etymological roots in medicalised notions of home sickness. The term now connotes a yearning for lost times and places, with as much concern for the temporal as for the spatial (see also Blunt, 2003). Hutcheon's observations consequently link to current criticisms of nostalgia's distorted/disordered imagination of the past. She suggests that nostalgia evokes an idealised past through notions of memory and desire, and that it is often criticised as partial, idealised and sanitised ('inauthentic'), reflecting the perceived inadequacies of the present. But such an argument ignores the selective nature of all kinds of remembering, positing an untenable distinction between history (as objective fact) and nostalgia (as subjective invention). We explore these ideas further, below, in relation to our own empirical material.

Responding to earlier calls for a rematerialisation of social and cultural geography (Jackson, 2000; Philo, 2000) and following those who suggest that both objects (Appadurai, 1986; Hoskins, 2007; Reckwitz, 2002; Shove, Watson, Hand, \& Ingram, 2007) and spaces (Hockey, Penhale, \& Sibley, 2005) have their own agency, we focus on the materiality of kitchenscapes 
- actual and remembered - and how these carry a'sedimentation of significances' (Hockey, Penhale, \& Sibley, 2001, p. 755) for those who inhabit them. Here, we continue the task that the first author started elsewhere (Meah, Under review), where she began to revision the modern kitchen as site in which memory, mood and agency are materialised. While this earlier discussion explored these issues through the lens of consumption - in terms of how individuals design their kitchens, their use of particular appliances and intermediaries, and what these make possible - in the present paper, we draw upon data from two ethnographic studies of domestic practice to argue that the kitchen can represent a site of memory within the wider domain of home, which itself can be understood as a kind of private museum; a space in which objects of personal, artistic or cultural interest are stored and displayed to narrate the untold stories of lives being lived (Gregson, Metcalfe, \& Crewe, 2007; Llewellyn, 2004a), those having been lived and those which are imagined (now and into the future) within them.

Explored at a macro level, kitchens have much social, cultural and historical significance; they clearly blur the lines between public and private. ${ }^{4}$ However, as Hand, Shove and others have illustrated via their work on the changing dynamics of the kitchen (Hand \& Shove, 2004; Hand, Shove, \& Southerton, 2007; Shove, Watson, Hand, \& Ingram, 2007), it is no longer (if it ever was) a depersonalised 'laboratory' (Lloyd \& Johnson, 2004, p. 264) or 'machine for the preparation of meals' (Llewellyn, 2004b, p. 234). Aside from their reconstitution as 'the symbolic heart of the home' (Hand et al., 2007), kitchens can also be intensely personal spaces in which encounters with food and other objects play a role in mobilising the sensory, haptic and kinetic dimensions of memory, through a combination of taste-, sound- and smellscapes and mundane activities which are embedded in the rhythms of everyday life. It is to the sensory dimensions of memory that we now turn.

\section{Memory, embodiment and the senses}

While few geographers have attended to the ways in which memory is invoked through the senses, ${ }^{5}$ the relationship between food and memory - mobilised through the senses - has become a common trope in contemporary food studies (Jackson, 2013). Indeed, the Proustian moment, the conjuring of involuntary memory and transportation back to one's childhood by means of a particular taste or smell is something to which many people can relate. In his anthropological review of food and memory, Jon Holtzman (2006) highlights the power of food in maintaining spatial and temporal connections, which facilitate both reflective memory of past events and experiences, as well as prospective memory of anticipated rituals and celebrations - a Christmas or Thanksgiving dinner, ending a fast during Ramadan.

This poly-temporality has featured in anthropologist David Sutton's (2011) discussions of food and memory, in which he suggests that 'people use their memories to call upon the past to interpret, contextualise, or simply link the present with the comfort of the known past' (ibid., p. 473), particularly in the context of modernity, which has 'increasingly encouraged forgetting' (Sutton, 2008a, p. 87). ${ }^{6}$ It is in a climate of concern regarding a potential lost connection with the past that accounts of food in bygone days are frequently imbued with nostalgia, defined by Davis (1979, p. 37) as 'memory with the pain removed'. Indeed, Sutton (2008b, p. 169) observes: 'Like all memories, memories of food are prone to [a] kind of telescoping in which the idealized aspects of the past are what are best recalled'. 
For Sutton, whose work represents the most comprehensive analyses of food and memory, ${ }^{7}$ it is the sensuality of food, how it crosses over - via processes of synaesthesia, with different sensory registers - that makes it a particularly compelling medium for memory $(2001,2011)$. Indeed, somewhat provocatively, Sutton (2011) speculates as to what it might mean, for food studies, to think of memory itself as a sense. He also suggests that food can be used proactively to create memories, as is the case with a meal served to migrating Kalymnians in order to provoke subsequent memories of home (2001). While Sutton's arguments concerning the relationship between memory and the senses are - most obviously - implicated in taste and smell, he (2006) suggests that memory is also embodied, haptic and kinetic, since it comes together with the senses and skilled practices - habit memories, or a'remembrance of the hands' (Connerton, as cited in Sutton, 2006, p. 89) - prompting him and Michael Hernandez to question: 'what might it mean to speak of cooking memory as residing not in our heads, but in our hands?' (Hernandez \& Sutton, 2003, p. 31). These ideas resonate with geographers who have also emphasised the embodied character of memory; for example, Bhatti et al. (2008, pp. 71-72), who have suggested that: 'If our memories are a form of knowledge about ourselves ... they are sourced by the past through our bodies in the form of interactions between haptic perception, the senses, tactile experiences, and movement'.

But what of space and place - how do these figure in mobilising recollections of food? While space (and time) is clearly implicated in Lahiri's (2011, p. 861) work in which tastescapes of Kolkata revolve around memories of the consumption of prohibited street food infused with the taste of the street, it is mainly in the anthropological literature that the sensory and embodied dimensions of food memories have been foregrounded. Reminded that embodied memories take root and attach themselves to specific spaces and objects which may be a monument, a heritage site, a veteran's medal or a rolling pin - we attempt to contextualise the sensory, haptic and kinetic dimensions of food memories and the individuals associated with them, in specific sites of memory: kitchens. While museums are sites in which objects of public or national interest are stored and displayed, for individuals, embodied, habit memories - achieved through repetition and often stored unconsciously - are embedded in more ordinary, personal spaces, which narrate their lives and experiences. The most ordinary of these spaces is the home, at the centre of which, either in real or imagined terms, is the kitchen, often perceived - if not experienced - as its symbolic heart (Hand et al., 2007). In the remainder of this paper, we attempt to recast the home and especially the kitchen as a private living museum. Following Hockey et al. (2005) and Hoskins (2007), who suggest that both objects and spaces have their own agency, we focus on the materiality of the kitchen and individuals' remembrances of specific items or objects - a table, a dodgy stove, a brand of tinned meat - and how the kitchen can become both a repository for and a carrier of memory - physical, symbolic and embodied.

\section{Methods}

The data reported here emerge from two ethnographic studies, based largely in the Yorkshire and Midlands areas of the United Kingdom, undertaken between February 2010 and July $2014 .{ }^{8}$ The first, CONANX, ${ }^{9}$ emerged from a concern to examine the alleged decline in domestic cooking skills/knowledge and concomitant increase in foodborne disease. It focused primarily on patterns of continuity and change in families' domestic kitchen practices within 
living memory, exploring the extent to which there is empirical evidence to support the current 'discourse of decline.' The first author, Angela, interviewed 23 members - aged 17-92 - of eight families, with at least two generations represented in each family. ${ }^{10}$ Ethnographic observation was completed with fifteen of the seventeen participating households. The second, BaM,11 was a pilot study exploring domestic masculinities and was designed to address the performative character of social life. This meant that in addition to exploring men's narrative constructions of 'being a man' through in-depth life history interviews, Angela also spent time 'hanging out' with the research participants and their children, observing some of their everyday practices (cf. Evans, 2011). The work involved three men, six of their children and two of the men's partners. ${ }^{12}$

Since both studies were underpinned by a theories of practice approach ${ }^{13}$ and a concern with exploring both the 'doings' and 'sayings' of practice, our choice of methods combined discursive reflections and observations of practice. Both studies involved in-depth life history interviews with all participants aged 17 and above. ${ }^{14}$ In the case of CONANX, these were framed around participants' memories of food, enabling them to speak about their memories of kitchens from their childhood and earlier lives, as well as those currently occupied, and the individuals who inhabited them. In BaM, the focus was on how the participants learnt to 'become a man' through changes across the life course with less-specific emphasis on memory.

In CONANX, Angela accompanied participants on provisioning 'go-alongs' (Kusenbach, 2003) at supermarkets, local shops and markets, and to allotments and gardens, in addition to video-recording and photographing guided kitchen tours and meal preparation. ${ }^{15}$ This approach enabled Angela to engage with participants' stream of experiences and practices as they moved through, and interacted with, their physical and social environments (Kusenbach, 2003, p. 463). Their encounters, including those with objects, became spontaneous means of elicitation. For example, spotting a particular brand of tinned meat pie while accompanying a mother and her adult son on separate shopping trips elicited different recollections of a now-deceased husband/father. The visual material has provided a rich archive for subsequent reflection, selected images having been made publicly available via an online gallery. ${ }^{16}$

BaM differed, in that Angela recorded more general hanging-out activities with participants and their families and friends. This included mundane running round with children at the weekend, as well as everyday domestic chores fitted into the routines of work and school. They also included social gatherings, where Angela shifted from 'researcher' to 'friend'. Participants in this study were also left with video-recorders and small tripods which allowed them to record a wider range of activities and practices at different times of day and days of week in the researcher's absence. The aim here was not simply to engage participants as collectors of data but, via participation in a subsequent reflexive interview, to engage with them as co-producers of meaning. ${ }^{17}$. Because each research participant was either a single father or was largely responsible for cooking in their household, Angela's visits often coincided with evening meal preparation, and some interviews were conducted while the participant was cooking, Angela sometimes staying to eat with the family. Likewise, much of what our participants themselves recorded took place in the kitchen (although not always relating to foodwork), pointing toward the centrality of the kitchen within their domestic lives. Indeed, all of these kitchens hummed with life and meaning that went beyond the preparation of food (see Bennett, 2006; Wills, Meah, Dickinson, \& Short, 2015). While narrative interviews 
emphasise the discursive dimensions of participants' experiences and perceptions, in both studies, the ethnographic work offered the advantage of capturing how domestic 'kitchen life' (Wills et al., 2015) is enacted and performed in each household, facilitating what Pink (2004, p. 10) has referred to as an'anthropology of the senses'. While none of these methods is particularly'novel' in itself, there are few examples in the literature on food/kitchens of life history interviews being combined with the range of ethnographic methods deployed across these studies, particularly not in relation to the multi-generational dimension of CONANX. ${ }^{18}$ Not only does this make visible how practices might be transferred (or rejected) across the generations, but it also highlights the ways in which the act of remembering is experienced and performed by different generations within the same family. Our current focus on kitchens as a site of memory was but one of many themes to emerge from the data. ${ }^{19}$

In what follows, we illustrate how our combination of methods across these studies provided opportunities to explore the ways in which memory is embedded within both the fabric of the kitchen and everyday encounters in domestic space, and how counter-nostalgia - which challenges that form of memory which yearns for an idealised past - is invoked in the remembrance of kitchen rituals which precede 'modern times'. We begin with the latter, exploring how - via discursive reflection - kitchens provide a conduit into the past, juxtaposing nostalgia for a return to a 'golden era' of cooking with the realities of everyday life experienced by women who grew up in an earlier time.

\section{Kitchens as a conduit to the past}

While the burgeoning scholarship on memory has tended to focus on nostalgia as a false or distorted form of memory, others have taken a less judgemental approach in conceptualising the term. Like Hutcheon, Blunt (2003) has identified the spaces of home as specific sites in which nostalgia is deployed: 'Whereas sites of memory often invoke, but also extend far beyond, spaces of home, nostalgia invokes home in its very meaning' (2003, p. 717).

In contrast with those who have highlighted the role of memory and nostalgia in 'distorting' the past (e.g. Hewison, 1987), others have emphasised the way in which present circumstances always inform how the past is remembered, ${ }^{20}$ exploring how memory is 'cultivated' and wrapped up in 'ideological mists' (Wright, 2009). Also emphasising the role of the present in informing representations of the past, Lowenthal (1985, p. 214) notes that memories continually change to conform with present concerns. Moreover, Lowenthal observes that: 'The need to use and reuse memorial knowledge, and to forget as well as to recall, force us to select, distil, distort and transform the past, accommodating things remembered to the needs of the present' (ibid., p. 194).

This became evident through the narrative interviews carried out in CONANX, during which Angela invited participants to 'tell me about the kitchens of your childhood', or asked 'what are your earliest memories of food?'. These questions elicited detailed accounts of both the fabric and the rhythm and routines of kitchen life during their childhood and youth which, for some, took place during the inter-war period - that offered a counter-narrative to public discourses which imagine a golden era of domestic cooking, part of a long-term narrative of decline. Although based on slender and increasingly dated evidence (e.g. Caraher, Dixon, Lang, \& Carr-Hill, 1999), in the UK, both popular and policy discourses alleging the decline of cooking contrast an imagined halcyon past - in which good wholesome food was cooked from 'scratch' with fresh, raw ingredients - with the culinary ignorance assumed of 
the present period. However, as has been illustrated elsewhere (Meah \& Watson, 2011), our participants' recollections often enabled us to contest this view, some being very assertive in reporting a lack of skill or imagination on their mothers' part, or highlighting the prevalence of overcooked vegetables, which was what 'everyone did in those days really'. Moreover, in relation to our project's principal focus, one woman suggested that it was not fair to 'generalise like that ... making us out to be saints with food hygiene and younger people not, and I don't think that's true' (see Meah \& Watson, 2011).

Other participants spoke of the great hardships endured by women and girls, upon whom the responsibility of cooking and provisioning fell during the inter- and post-Second World War periods; hardships which are omitted in romanticised reconstructions of the past. For example, some foregrounded the ways in which non-food activities determined the routines of kitchen life and the food that was consumed on particular days. Sarah Dexter (87) reported that when she was a child, Monday was wash day, an activity which 'took most of the day'. Consequently, cold meat, leftover from the previous day's roast was served for the family's midday meal: 'we didn't get much on wash day ... we had cold meat on Mondays and I remember thinking it wasn't very nice, not very tasty'. Contravening contemporary food safety guidelines, Sarah recalled that leftovers from Sunday lunch - often reconstituted as a stew or shepherd's pie, created with the aid of a hand mincer, a practice also reported by other participants - would be eaten until the following Wednesday.

A younger woman, Mary Green (68) spoke in great detail about her childhood in rural Ireland, where there was neither electricity nor running water, and - during dry periods 'every drop of water you used had to be dragged in buckets across the fields'. In the absence of a sink, 'you had a bowl of water on the big wooden table', where freshly dug vegetables would be peeled only after the bulk of the earth had been rinsed off outside:

it was all done on the kitchen table with a little bowl of water. So you didn't have that hygiene that we have today, with the running water and everything. You had to do the best you could with very limited resources.

Mary's reflections continued as she set about preparing a meal, her use of an anti-bacterial spray prompting the following observation, which directly challenges how the idealised past is represented in public discourses:

When we were children, dad would kill the chicken outside and he would pluck it and everything else. There was no real hygiene as such ... [it would be taken in and prepared on the wooden kitchen table] which was scrubbed very carefully every day. Mom was hygienic, but not in the same way as we are today.

Simple objects, such as the table and the open-fire, were the focal point of many of Mary's recollections. For example, she reported how her mother did all the family's cooking over an open-fire, something which she considered to be 'an art'. Of this, she says:

They had a big open fire and a bracket on the back of the fire with a swing thing that came out, and you could fit so many pots, and skillet, that was what you baked bread on, and then there were pots and kettles... And she, she manoeuvred things according to whether she needed it really hot directly over the fire or a little bit further away ... She was a good cook and it was good food and rarely ever burnt, don't ask me how.

Mary's mother is depicted as a skilful artisan whose embodied knowledge of variations in the intensity of the fire and heat required to cook multiple meal components simultaneously (cf. Silva, 2000) enable her to produce food which lingers in her daughter's memory long after her mother had died. 
The oldest of our participants was Agnes Faulkner (92). Her narrative contained little of the nostalgia imagined in contemporary discourses which appeal for a return to a period of 'lost skill' and close connection with food. Agnes was born in 1918, the only female among four children. Although born into a relatively privileged family, she nonetheless reports that 'times were hard, very hard', and that 'there was an atmosphere of concern' when she was growing up. Unlike her brothers, she was expected to remain close to home in the event of her mother, who suffered with 'seizures', falling ill. Even the Second World War did not bring her the kind of independence experienced by other women - such as Sarah Dexter, who joined the Women's Auxiliary Air Force - as 'mum was more important'. So while her brothers were educated and had careers, Augusta entered a life of caring for others; first her mother, and then her husband and children. While her husband grew much of the family's food on their allotments, Agnes reported that she was not involved in cultivation, but that 'my responsibility was to cook them and make sure they were cooked perfectly [laughs]'. While the family were lucky that they at least had some fresh food, Agnes was at the mercy of poor, inadequate equipment. Here, she speaks of the challenges of operating an uneven cooker, damaged by an explosion in the area:

It was a cooker like my mum's and unfortunately there'd been a vast explosion a few miles away and, er, it'd, erm, it'd affected part of the house and ... erm, it'd also, er, cracked or cracked part of the oven, so that the oven bottom was never level, so, erm, I had this job of finding something that I could put in there that wouldn't burn, you know, some, a rock or tile or something to try and level it off. I didn't mind, er, when I was just cooking an ordinary meal, meat or anything like that, but when it came to a, er, a cake....

Prompted by Agnes' son, Frank (65), who had previously observed: 'it's no wonder women of my mother's generation hated cooking given that they didn't have good quality foods and the technology they had to work with was unreliable', Angela asked Agnes whether she enjoyed cooking and being a housewife. She responded: 'I felt resentful. I felt resentful all the time, right to the end, you know, although, not all the time, but much of the time I was resentful'.

Meanwhile, Sarah Dexter reported that the hardships she had experienced as a young person between the Wars did not lessen after her marriage, when - living on a remote farm in Northern England - she had eight children to care for, one of whom was severely disabled, along with tending to their livestock, with little and then, later, no help from her husband. With no access to a car and tied to the demands of caring for a very disabled child, Sarah was dependent on the travelling shops which came each week. Contesting discourses which admonish contemporary use of 'convenience' foods and invoke a return to an imagined golden era of cooking, Sarah reports:

Sometimes, if I was in a hurry (.) I would just open a tin of mince, because the travelling shop came round with loads of tins, there was no fridge or freezer on anything there, so we did use a lot of tins. Tinned peas and stuff ... so l'd open a tin of beans and mince or whatever, erm, and make a meal out of that, and I always had plenty of potatoes from the garden, we had greens, plenty of greens, always had cabbage ... I'm trying to think what we got from the travelling shop ... tins of Spam ${ }^{21}$... and that's really nice ... and you could fry it as well ... yeah, you've got to create shortcuts all the time ... I used to make a lot of pilchard fishcakes.

This was confirmed by Sarah's daughter, Jenny (54), who recalled: 'We used to have a lot of corned beef'.

Given the current moralisation of convenience food, it is significant that Sarah explicates the practical and logistical conditions in which she had to 'create shortcuts' while also 
referring to the active process of 'making a meal' by combining fresh ingredients from her garden with shop-bought food. ${ }^{22}$ While nostalgia is frequently invoked in accounts of the past written from a disappointed sense of the present (Watson \&Wells, 2006), the participant accounts reported here clearly illustrate that - at least in the context of cooking and eating - the rhetoric of decline may be running ahead of the evidence.

\section{Curating the past}

The discussion in the previous section makes visible the ways in which kitchens - and related domestic routines - from the past are constituted in talk, providing a narrative doorway into earlier periods in our participants' lives. In the following sections, we explore how this is achieved via the observation of domestic practice. For Hockey and colleagues (2001), memories are bound up within the material spaces of the home, which becomes a valuable storehouse of moments, reflections, experiences and material objects which testify to these. Some memories may be intricately bound within the fabric and structure of a particular space or dwelling, having their own stories to tell (see for example Meah, Under review), others are more portable and may accompany an individual over the life course as they progress through their housing career (Murdie, 2002). It is to these stories that we now turn. In the first, we focus on a kitchen tour with Ailsa (67) and Michael (68) Charles to illustrate how the past is remembered through the careful curation of material objects, while the second focuses on the way kitchens enable the process of materialising memory and other kinds of existential identity-work.

Both Michael and Ailsa Charles are professionals - Michael was in the process of retiring at the time of interview; his wife was a successful writer. Their home, which the couple have occupied for over 30 years, is a renovated farmhouse located in a small village in North Yorkshire; part of the building dates back to the 1680s, while the 'back kitchen' extension was built in the 1700s. The couple took Angela on a tour of the property, showing her the original kitchen - now essentially an overspill kitchen which acted as a kind of wine-cellar and where they stored an extra fridge and freezer and hung their laundry to dry. This had originally been a stable which they had converted into a galley kitchen when they first acquired the property. Their primary kitchen was moved to its present position in 2005. While 'shades of the old kitchen' could be observed in the back kitchen via the dated electrical sockets and clothes airer which hung from the ceiling, the new one was fitted with ivory 'shaker' units. While offering modern storage solutions, such as integrated appliances and pull-out storage, the kitchen was designed to convey a rustic character, in keeping with the house. Glass display units revealed a collection of glass, crockery and stainless steel items; dried herbs hung from the ceiling, wicker baskets of different shapes and sizes were stored along a row of wall units, and there were ceramic items and a framed cross-stitch picture which had their own stories attached to them.

On one side of the kitchen, there was a collection of recipes and cookbooks. Ailsa immediately drew Angela's attention to these, removing a binder which - she informed her - was a gift from her son who lives in the US; it was 'a typical American sort of cookbook', she said, offering wallets in which loose recipes could be stored. Ailsa reported that whenever they visited friends in the US, they would 'always come back with something amazing, so that's a good one for keeping [things in]'. Leafing through the recipes, Ailsa pulled out a handwritten Christmas cake recipe that belonged to an old friend in the village, also showing Angela 
her mother's prize-winning fudge recipe. Of this collection of discoloured, fragile-looking handwritten recipes Ailsa said: 'I do tend to keep the people's writing because that means something ... So this is a sort of archive really'. She also showed Angela what appeared to be an old exercise book, falling apart at the seams, which stored another collection:

This is the original one that my grandma gave me, and I've got all the recipes of my friends. Some of them have got the date on, or the person that gave me them, and I can't bear to part with that, so it's falling to pieces. (see Figure 1)

For Ailsa, her collection of handwritten recipes is about preserving 'traditions'.

While some - such as her mother's fudge recipe - are of obvious personal or sentimental value, others are perhaps less so, the value coming from their connection with the individual, via their handwriting. As with tools and other objects found in the kitchen, these recipes are what Weiner (1992) has described as 'inalienable possessions': objects which, because of their association with social memory and personal identity, are removed from normal circuits of commodity or gift exchange (Sutton \& Hernandez, 2007). While both Nora and Sutton, in their respective projects, are concerned with the practices and rituals which facilitate collective memory, for Ailsa, her 'archive' is a very personal responsibility. Rather than discard these increasingly worn and fragile sheets of paper, she assumes the role of 'curator' in preserving this collection, acknowledging that she makes a point of including recipes from the collection in many of her novels (set during the Second World War). Ailsa assumes responsibility for seeing that particular traditions are not forgotten, and that 'they form a continuity with the past within the transient domain of material objects we transact with in the kitchen' (Sutton \& Hernandez, 2007, p. 67).

On the other side of the kitchen, Ailsa and Michael showed Angela a selection of stainless steel tableware which had been produced by previous generations of Michael's family (see Figure 2). There are serving dishes, a coffee pot, a tea set and cutlery, in addition to a small pan and a long stainless steel plate on the floor in front of the range cooker, designed to

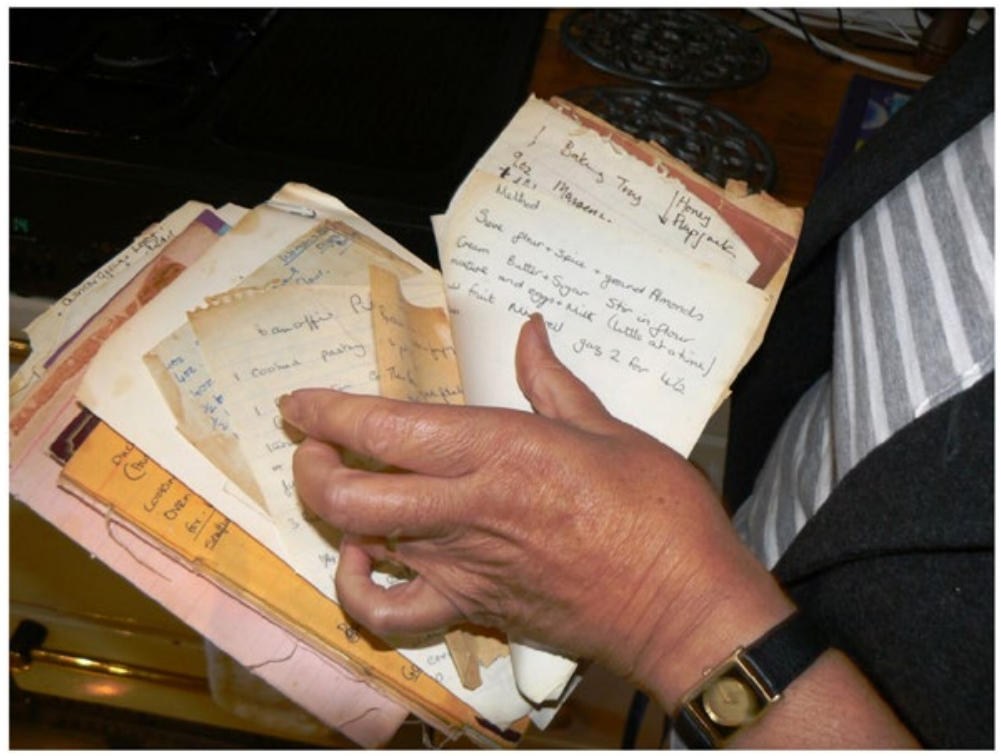

Figure 1. Ailsa Charles' collection of handwritten recipes. 


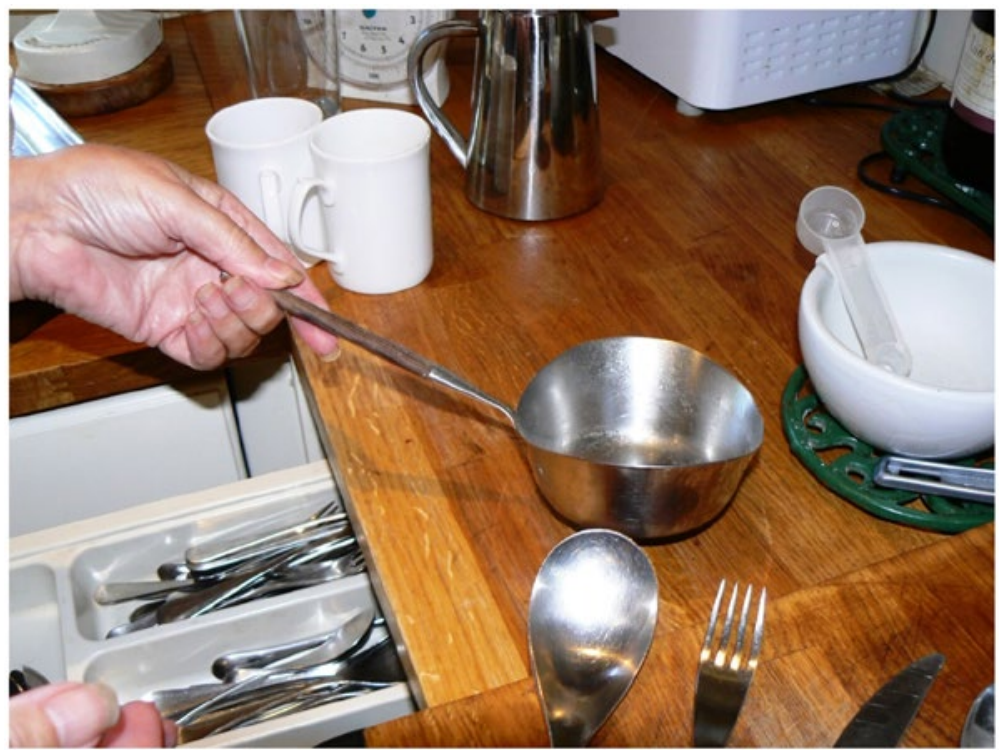

Figure 2. A source of pride, and debated provenance.

protect the floor during cooking. While Michael informed Angela that the tableware was now becoming valued by antiques dealers, and that one of their children had started to invest in this, both the pan and the footplate, Ailsa reported, belonged to Michael's mother; the latter having been made for her by the family. As they showed her these items - with Ailsa taking the lead in providing the accompanying 'story' - an exchange occurs which highlights the potentially unreliable or disputed nature of memory, when one individual questions the recollection of another. Here, Michael queries the provenance of the pan: 'Is it [name of company]? ... I'm not so sure it is' and Ailsa responds: 'I think it is. She was very proud of that'. It is perhaps the case that the memory of his mother's pride in the pan is conflated, by Ailsa, with a recollection of its origin (see Figure 2 ).

We conclude this case study by illustrating another of Ailsa's practices which point toward her having adopted the role of curator in preserving her family's history, a practice which - in itself - both represents a lieu de mémoire - a ritual of symbolic significance - as well as creating a physical site of memory. Ailsa drew Angela's attention to a practice that was 'very (.) of our generation': this was that 'you were expected to have a bone china collection ... the old idea of having wedding china, your best china'. No longer in everyday circulation, some of these items are wrapped in tissue paper and interred in a cupboard, perhaps undergoing some kind of 'first burial' (Hetherington, 2004) before they are divested among members of the family who may, or may not, attach the same kind of significance to them as Ailsa does to those she and Michael inherited from their own mothers, and Ailsa's grandmother. Because of their sentimental value and delicate nature, such items are on display in the dining room. Of these, she says: 'I have given some away. I've only got bits for sentimental reasons, and I have given them away to members of the family, as if to say, "well this is a piece of family history"'. Whether her children share her interest in preserving their family history via these material objects is not known, but the implication seemed to be that Ailsa assumed the role 
of curator of, and spokesperson for, the collection of inalienable possessions found within her and Michael's kitchen.

\section{Materialising memory}

In his work on the Greek island of Kalymnos, David Sutton (2008a, p. 86) expounds the notion of 'existential memory work', which he explains in terms of 'the ways people's orientation toward the past is felt to be an intrinsic part of their selves and subjectivities'. In the context in which he writes, Sutton is referring to the ways in which Kalymnians draw upon memories of the past and notions of 'tradition' and 'modernity' through everyday practices and discourses about food and domestic life, in how they negotiate the present and think about their future - the poly-temporality referred to earlier. In our second case study, we explore how Sutton's ideas concerning existential memory work can be applied to one of the kitchens in BaM.

This kitchen belonged to Darren (45) and Carol (39) Huntingdon and was also occupied by their two children - Billie (5) and Charlie (7). The life story interview with Darren took place over two Friday evenings while he prepared meals to be consumed over the weekend. Although Angela's work with the household was not focused on kitchen practices in the way that the previous study had been, she was nonetheless fascinated by the fabric of the kitchen since this was a space which most vividly narrated the lives being lived, and those having been lived within it. While many of the kitchens Angela has visited over the years concealed their contents behind sleek rows of white doors, or their possessions were aesthetically displayed, Darren and Carol's kitchen was a space in which both their tastes and preferences and markers of their family's life all 'hung out'.

Although Darren and Carol both cooked and had collaborated in designing the kitchen, this was, nonetheless, identified by both as 'his' space. Both Angela's own observation and Darren's self-recorded footage revealed that, here, the radio or some beloved jazz album (sometimes both simultaneously) would provide the soundtrack to cooking and routine domestic tasks, including supervision of the children. This was a space into which he could retreat and indulge his dual passions of cooking and listening to music, loudly.

During Angela's interview with him, Darren drew upon the materiality of the kitchen to illustrate moments in his life that he described. What might initially appear as ephemera in fact documented key moments and embodied their family history within the fabric of the space. For example, when asked how old he was, he pointed to one of many framed iconic music posters advertising concerts which were on display throughout the house, the kitchen included; this one was particularly special: Aretha Franklin topping the bill at New York City Philharmonic on the day of his birth. As can be seen in Figure 3, vertical surfaces were adorned with a range of items - photographs, ticket stubs and children's paintings informally pinned to a notice board or randomly stuck to the fridge or central heating boiler. In contrast with more formal, framed images or artefacts which are often subject to particular displaying practices (cf. Percival, 2002; Rose, 2003), the images and items adorning this kitchen represent a vibrant collage of snapshots, illustrating particular moments in time: a photograph from the couple's wedding; another taken with an Elvis impersonator on their honeymoon; children's parties; a walk on a beach; the children's christening invitations; a self-portrait of their daughter, Billie; a child's handprints. Many are seemingly self-explanatory, although a small photograph of an infant Charlie in a football strip prompted Darren 


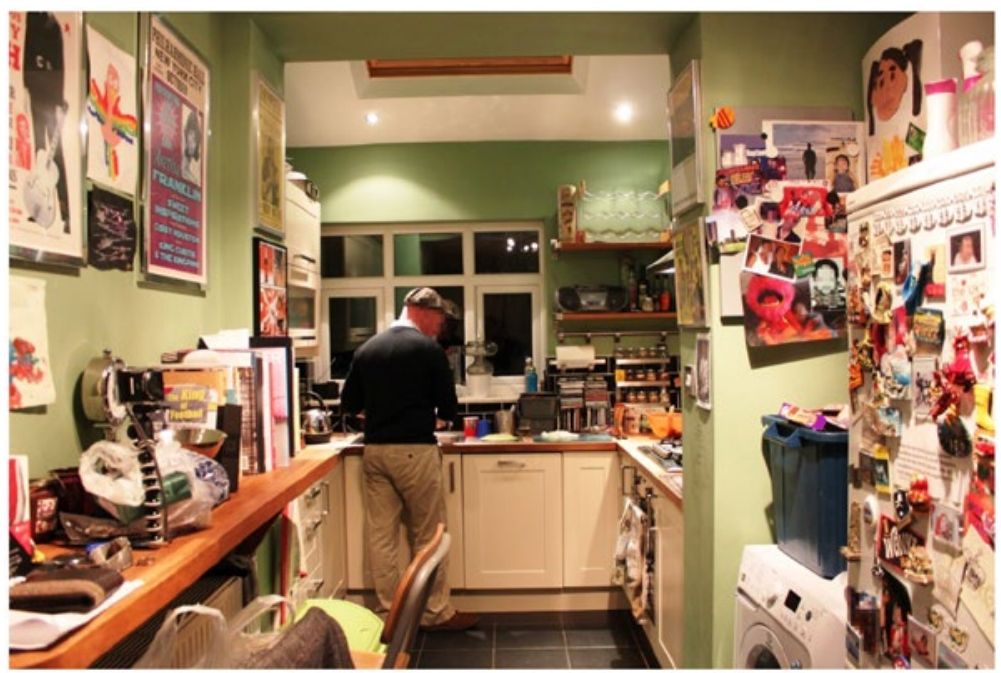

Figure 3. Darren's kitchen.

to report his pride in taking his son to his first ever match when he was one-month old. The ticket stubs, however, required further explanation. Darren beamed as he talked Angela through these:

KISS was [baby] Charlie's first ever gig. Carol was seven months pregnant with him at the Chilli Peppers, and seven months with Billie at Mary J Blige. The Specials was the second gig they did when they reformed in 2009 and possibly the best concert I've ever been to, definitely in my top 5 ... I've always kept ticket stubs but tend to lose them when moving house and that.

While these items - along with the snapshots and paintings - illustrate the portability of memory, and how easily a space can be transformed into a place to create a sense of belonging and attachment, Angela's attention was also drawn to something which demonstrated the embeddedness of memory within the actual fabric of the building. There was one area (to the left of the washing machine in Figure 3 ) which was seemingly bare. On closer inspection, this was revealed to be a height chart on which the children's growth had been marked - from 2010 until Charlie had run out of space shortly before the fieldwork started (see Figure 4). The wall literally bears the marks of the children growing up and memories of the fun in undertaking this activity will remain here when the children, or the family, have moved on.

As with Ailsa and Michael Charles, Darren's kitchen also contained inalienable objects which link members of the household to those beyond, some living, and some dead. For example, when Angela first met the couple, Carol informed her that when she and Darren had got married 10 years earlier, her mother had bought them a Dutch oven ${ }^{23}$ and made it clear to her new son-in-law that the tradition when a man marries into a Jamaican family is that he has to cook a meal for his in-laws. Carol reports: 'she taught him a few dishes and he's never looked back'. The cooking pot - made of unpainted cast iron and embossed with a pattern in the side - is a tangible reminder both of the couple's marriage and - perhaps more importantly - Darren's acceptance into his wife's Jamaican family. It continues to be used within his everyday cooking, and Angela observed it in use the first time she interviewed him. On this occasion, he prepared a Caribbean beef stew with a 'Yorkshire twist' (the twist being the addition of a dash of Henderson's relish, a locally produced condiment). As he did 


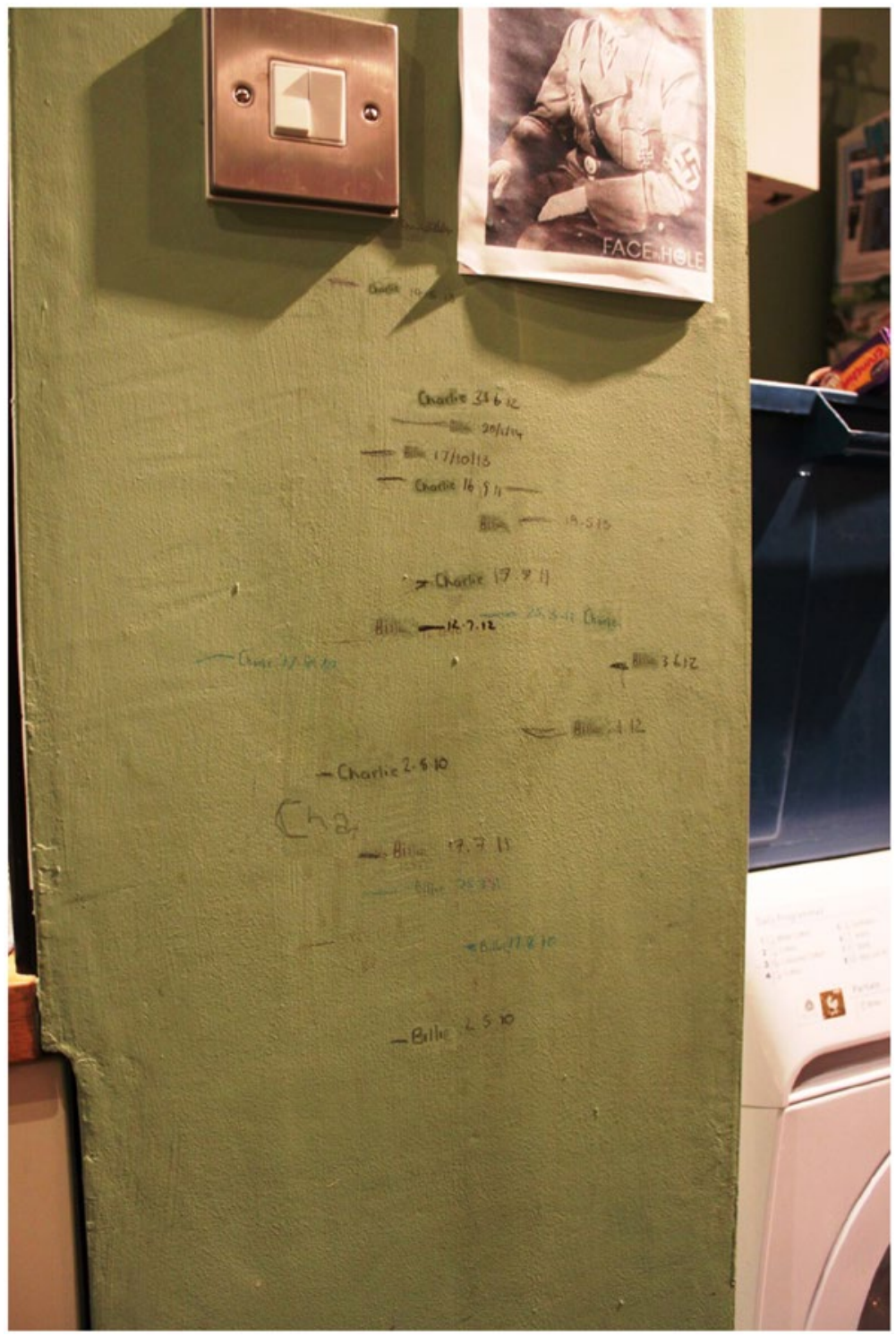

Figure 4. Billie and Charlie's height chart.

this, he spoke about his childhood and his relationship with his paternal grandmother, who had taught him how to cook and sew, and had provided a much-valued bolt-hole when he struggled to find his place in his reconstituted family after his father's remarriage. As he cooked and reflected, he produced a well-worn glass jug to mix a thickener which he added to the pot (see Figure 5). 'This was my grandma's', he says.

When asked about the jug later, Darren responded:

If memory serves me well, I got the jug off my grandma when she moved from her own flat into a care home. Memories of her with it are her using it when making gravy, adding water to meat and potato pie, it being full of very yellow custard served with her home-made apple pie. 


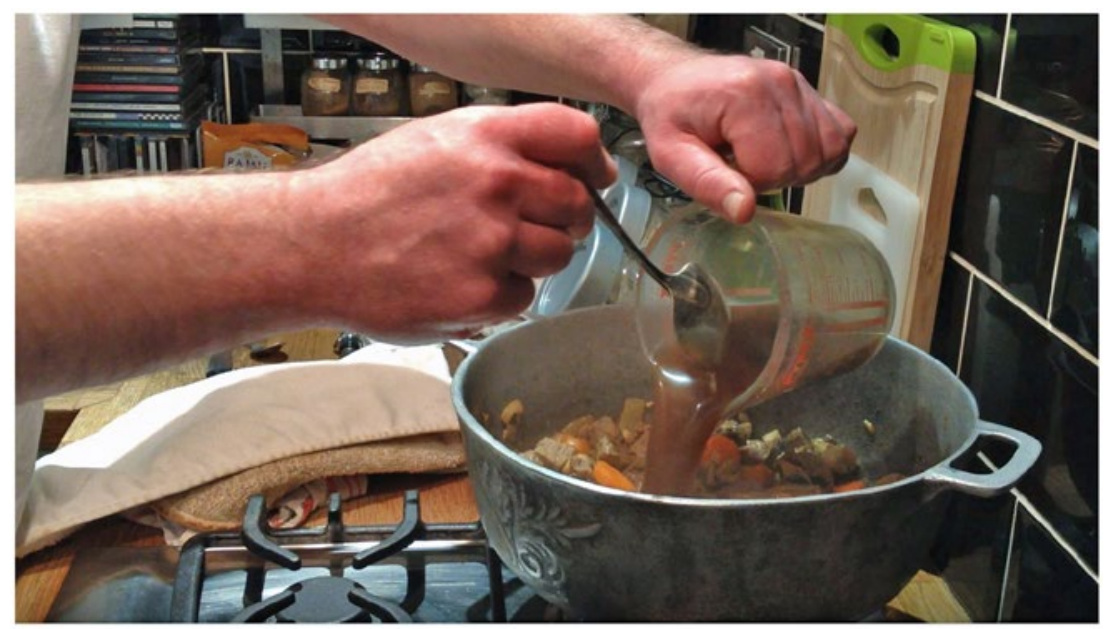

Figure 5. The Dutch oven and grandma's jug.

Both the pot and the jug are objects which materialise memory within this household: the pot having symbolic significance, the jug facilitating an embodied connection with someone significant in Darren's childhood; someone with whom he sought refuge within his family; someone who continues to influence his own cooking practices. For some scholars, items such as these become valued because they are constitutive of our family history or evoke memories and emotional connections with individuals who may or may not be living (Marcoux, 2001). While some items - as with Ailsa and Michael - may be objects of display and reminiscence, others - like Darren's jug - are incorporated within everyday usage in the present, and potentially have an imagined future use. An example of this can be seen in Pollack's (2011) essay where she reflects upon her grandmother's rolling pin. In conjuring memories of his grandma's bright yellow custard and home-made apple pie, when used in his own kitchen, Darren's grandma's jug becomes what Pollack describes as an 'evocative object'. It transports him back to the warmth of his grandma's kitchen, the sights and smells of her cooking, the time he spent and skills he learned with her. In doing so, Pollack (2011, p. 227) speculates: 'It anchors [one] in the past, yet continues to create memories for the future. The object becomes timeless'. In this sense, we see how - via inalienable possessions - the past both 'eagerly cohabits with the present' (Boym, 2001, p. 38), and has a prospective capacity.

\section{Conclusion}

In this paper, we have argued that memory work takes place in private domestic spaces as well as in the more public settings that have been the focus of most previous geographical work on the spaces of memory. Moreover, because of its inextricable connection with home, we also challenge conventional understandings which conceptualise nostalgia as a distorted form of memory. We do this less by deconstructing the nostalgia which might be assumed to characterise our participants' personal narratives, highlighting, instead, how the past has become idealised - at least in terms of food safety and cooking skill - within public discourses. Our life history interviews produce evidence which problematise the ways in which nostalgia is understood in the context of discourses of decline, as well as providing a more 
complex understanding of the ways in which memory and nostalgia - as a particular form of memory - are invoked at both the public and private level, explicating both generational change and the role of the past in shaping the present.

Importantly, too, this paper extends the ways in which the kitchen has been conceptualised among scholars (including geographers) who have been concerned with aspects of design, or social and cultural factors, examining it - instead - as a specific lieu de mémoire, a space that provides a context for the sensory, haptic and kinetic dimensions of memory which may, or may not, relate to food, but which certainly connects kitchens and their occupants to individuals and moments in time which may otherwise be forgotten. While the relationship between food and memory has been a common trope within contemporary food studies and anthropology - on the one hand, facilitating the maintenance of spatial and temporal connections, on the other, foregrounding the significance of habit memory in the performance of routine acts of cooking - a geographical perspective has yet to be brought to bear on the spaces in which these occur.

Drawing upon qualitative and ethnographic research and supported with visual evidence, we have suggested that the kitchen can be thought of as both a conduit to the past, as well as a kind of museum where items are displayed and material artefacts are carefully curated as part of the construction and reproduction of personal memories and familial identities, similar to the way that museums play a more public role in the construction of national identity; they narrate the lives of the people who occupy them. Unlike the kind of public monuments that Pierre Nora describes as lieux de mémoire, these are small-scale domestic sites but no less powerful as carriers of memory. The personal reflections on participants' lives documented here also demonstrate Nora's argument that memory is 'multiple and yet specific; collective, plural, and yet individual' ... taking root 'in the concrete, in spaces, gestures, images, and objects' (1989, p. 9). Ailsa's archive of handwritten recipes and collection of generations of wedding china both preserve traditions and set her up as curator of her family's history. In Darren's case, his kitchen hums with artefacts which bear witness to moments in time shared with his wife and children; but here, too, are inalienable possessions which facilitate poly-temporal connections between moments and people from Darren's past which also have an imagined future role in his kitchen, wherever that may be. For both Darren and Ailsa, memories of their relatives and their kitchen practices are not consigned to the past, but - via the appropriation of a recipe or the use of a jug - are both memorialised and given the opportunity to live on for an indefinite future. These case studies clearly demonstrate - via an examination of the poly-temporal role of material artefacts in curating the past and in materialising memory - the ways in which the past infuses the present and potentially the future.

Additionally, our interviews with older women reveal counter-narratives of everyday cooking which seemingly contradict popular contemporary discourses regarding bygone practices during an alleged golden era of cooking. Such discourses - which are wrought by present-day concerns with a long-term narrative of declining domestic skills - actively shape how the past is constructed at the public level, also reminding us of the political dimension which not infrequently underpins public remembering. Combined, these narrative, ethnographic and visual data furnish a more complex and nuanced understanding of the role of the kitchen in facilitating memory than previously available. Moreover, it is an understanding via which the past can be seen as permeating the present through the everyday practices of individuals in their kitchens, as well making visible the ways in which present-day concerns are revealed as actively shaping public discourses for a return to a 
nostalgic past which may have little bearing on lived experience, particularly not among those women and girls who shouldered the burden of cooking and provisioning prior to the advent of the 'modern' kitchen.

\section{Notes}

1. See, for example, Johnson (1995), Marshall (2004), Muzaini (2013), Sarmento (2009), Till (2003), Tyner et al. (2012), and Withers (1996).

2. Pierre Nora's Les Lieux de Mémoire was an heroic attempt to map the history and culture of France at a critical point of transition in the nation's consciousness during the Mitterrand years. Published in seven volumes (1984-1992) and translated into English as Rethinking France, it focused on the role of public monuments such as the chateau of Versailles, national institutions such as the Code Civil and works of national collective memory including the Larousse dictionary, as well as the cultural significance of French manners and mores. Nora sought to distinguish between 'history' and 'memory', addressing the affective and magical nature of memory which was, he argued, 'in permanent evolution, open to the dialectic of remembering and forgetting, unconscious of its successive deformations, vulnerable to manipulation and appropriation, susceptible to being long dormant and periodically revived' $(1989$, p. 8).

3. See, for example, Alderman (2003), Heffernan (1995), Hoskins (2007), Legg (2004), Marshall (2004), Muzaini (2013), Rose-Redwood (2008), Sarmento (2009), Till (2003), and Tyner et al. (2012).

4. There is extensive work on the kitchen produced by social and cultural historians, sociologists and geographers. See for example, Buckley (1996), Floyd (2004), Freeman (2004), Hand and Shove (2004), Hand, Shove, and Southerton (2007), Hayden (1978), Jerram (2006), Llewellyn (2004a), Meah (2014a), Reid (2009), van Caudenberg and Heynen (2004), as well as the special issues of Gender, Place \& Culture published in 2006.

5. Notable exceptions include the work of Marshall (2004) on war remembrance and Lahiri (2011) on translocality.

6. See also Seremetakis (1996) and Sutton (2001).

7. See for example, Hernandez and Sutton (2003), Sutton (2001, 2006, 2008a, 2008b, 2009, 2011, 2014) and Sutton and Hernandez (2007).

8. Participants in both studies were initially recruited in Sheffield and neighbouring townships, but snowballing (particularly within families) extended the geographic reach.

9. The project described herein was a work-package, concerned with food safety and consumer practice, which was part of a programme of research on Consumer Culture in an 'Age of Anxiety' (CONANX), funded by the European Research Council, 2009-2012. See https://www.sheffield.ac.uk/conanx/webpages/workpackage3.

10. Seven out of the eight households represented White families; one of the participants was Irish, rather than British. The eighth family was Pakistani, the younger generation being British-born. All but the Irish and Pakistani families reflect a highly motivated middle-class constituency, although social mobility within these families, particularly among the older generations, is significant.

11. 'Being a Man'. This pilot study was funded through the University of Sheffield's Faculty of Social Sciences.

12. All of the male participants were White, and aged between 45 and 51 . Two were single fathers with shared custody of their children; both had non-cohabiting partners. The third man was married to a British born Afro-Caribbean woman.

13. See Reckwitz (2002), Schatzki (2002), Warde (2005), Shove and Pantzar (2010), and Shove, Pantzar \& Watson (2012).

14. Interviews were digitally recorded and transcribed verbatim, each participant being assigned a pseudonym.

15. Contemporaneous reflexive field-notes were written in tandem with analysis of the audio and visual material, still images being taken from the video footage to capture moments of 
practice which took place when the digital camera was not in use and then embedded within field-notes where relevant.

16. See https://www.flickr.com/photos/52548860@N08/sets/.

17. We discuss this method in Meah (2014b) and Meah and Jackson (2014).

18. Sutton's work on the Greek island of Kalymnos is a notable exception.

19. Others have included food safety (Meah, 2014c), gender and cooking, (Meah \& Jackson, 2013), food waste (Watson \& Meah, 2013), consumer ethics (Meah \& Watson, 2013), materialisng domestic consumption (Meah, Under review) and a challenge to discourses of decline in relation to domestic cooking (Meah \& Watson, 2011).

20. See Jackson (1999), Misztal (2003), Steedman (1986), and Zerubavel (1996).

21. A brand of precooked meat, meaning spiced ham.

22. Warde, for example, describes how convenience food is 'tinged with moral disapprobation' (1999, p. 518).

23. A thick-walled cooking pot with a tight-fitting lid.

\section{Acknowledgements}

We would like to thank the editor and anonymous referees for their extremely useful comments and suggestions on an earlier draft of this paper. We would also like to express enormous gratitude to our participants in both studies who gave so generously of their time and opened up their homes and memories to us. We are particularly grateful to the older women who contributed to the CONANX project, the telling of whose stories increases in importance as their own memories fade.

\section{Disclosure statement}

No potential conflict of interest was reported by the authors.

\section{Funding}

This work was supported by the European Research Council and University of Sheffield.

\section{References}

Alderman, D. (2003). Street names and the scaling of memory: The politics of commemorating Martin Luther King Jr within the African American community. Area, 35, 163-173.

Appadurai, A. (1986). The social life of things. Cambridge: Cambridge University Press.

Atkinson, D. (2007). Kitsch geographies and the everyday spaces of social memory. Environment and Planning A, 39, 521-540.

Bennett, K. (2006). Kitchen drama: Performances, patriarchy and power dynamics in a dorset farmhouse kitchen. Gender, Place \& Culture, 13, 153-160.

Bhatti, M., Church, A., Claremont, A., \& Stenner, P. (2008). 'I love being in the garden': Enchanting encounters in everyday life. Social \& Cultural Geography, 10, 61-76.

Blunt, A. (2003). Collective memory and productive nostalgia: Anglo-Indian homemaking at McCluskieganj. Environment and Planning D: Society and Space, 21, 717-738.

Blunt, A., \& Varley, A. (2004). Geographies of home. Cultural Geographies, 11, 3-6.

Boym, S. (2001). The future of nostalgia. New York, NY: Basic Books.

Buckley, S. (1996). A guided tour of the kitchen: Seven Japanese domestic tales. Environment \& Planning D: Society \& Space, $14,441-461$.

Caraher, M., Dixon, P., Lang, T., \& Carr-Hill, R. (1999). The state of cooking in England: The relationship of cooking skills to food choice. British Food Journal, 101, 590-609.

Datta, A. (2006). From tenements to flats: Gender, class and 'modernization' in Bethnal Green Estate. Social \& Cultural Geography, 7, 789-805. 
Davis, F. (1979). Yearning for yesterday: A sociology of nostalgia. New York, NY: The Free Press.

Dwyer, O. J., \& Alderman, D. H. (2008). Memorial landscapes: Anayltics questions and metaphors. GeoJournal, 73, 165-178.

Evans, D. (2011). Blaming the consumer - Once again: The social and material contexts of everyday food waste practices in some English households. Critical Public Health, 21, 429-440.

Floyd, J. (2004). Coming out of the kitchen: Texts, contexts and debates. Cultural Geographies, 11, 61-73.

Foote, K. (2003). Shadowed ground: America's landscapes of violence and tragedy. Austin: University of Texas press.

Freeman, J. (2004). The making of the modern kitchen. Oxford: Berg.

Gregson, N., Metcalfe, A., \& Crewe, L. (2007). Identity, mobility, and the throwaway society. Environment and Planning D: Society and Space, 25, 682-700.

Hand, M., \& Shove, E. (2004). Orchestrating concepts: Kitchen dynamics and regime change in Good Housekeeping and Ideal Home, 1922-2002. Home Cultures, 1, 235-256.

Hand, M., Shove, E., \& Southerton, D. (2007). Home extensions in the United Kingdom: Space, time, and practice. Environment and Planning D: Society and Space, 25, 668-681.

Hayden, D. (1978). Two Utopian feminists and their campaigns for kitchenless houses. Signs: Journal of Women in Culture and Society, 4, 274-290.

Heffernan, M. (1995). For ever England:The Western Front and the politics of remembrance in Britain. Ecumene, 2, 293-324.

Hernandez, M., \& Sutton, D. (2003). Hands that remember: An ethnographic approach to everyday cooking. Expedition, 45, 30-37.

Hetherington, K. (2004). Secondhandedness: Consumption, disposal, and absent presence. Environment and Planning D: Society and Space, 22, 157-173.

Hewison, R. (1987). The heritage industry: Britain in a climate of decline. London: Methuen.

Hockey, J., Penhale, B., \& Sibley, D. (2001). Landscapes of loss: Spaces of memory, times of bereavement. Ageing \& Society, 21, 739-757.

Hockey, J., Penhale, B., \& Sibley, D. (2005). Environments of memory: Home space, later life and grief. In J. Davidson, L. Bondi, \& M. Smith (Eds.), Emotional geographies (pp. 135-146). Aldershot: Ashgate.

Hoelscher, S., \& Alderman, D. H. (2004). Memory and place: Geographies of a critical relationship. Social \& Cultural Geography, 5, 347-355.

Holtzman, J. D. (2006). Food and memory. Annual Review of Anthropology, 35, 361-378.

Hoskins, G. (2007). Materialising memory at Angel Island Immigration Station, San Francisco. Environment and Planning A, 39, 437-455.

Hutcheon, L. (1998). Irony, nostalgia, and the postmodern. Retrieved July 3, 2015, from http://www. library.utoronto.ca/utel/criticism/hutchinp.html

Huyssen, A. (2003). Present pasts: Urban palimsests and the politics of memory. Stanford, CA: Stanford University Press.

Jackson, P. (2000). Rematerializing social and cultural geography. Social \& Cultural Geography, 1, 9-14. Jackson, P. (2013). Memory. In P. Jackson \& the CONANX Group (Eds.), Food words: Essays in culinary culture (pp. 137-139). London: Bloomsbury.

Jackson, S. (1999). Heterosexuality in question. London: Sage.

Jerram, L. (2006). Kitchen sink dramas: Women, modernity and space in Weimar Germany. Cultural Geographies, 13, 538-556.

Johnson, N. C. (1995). Cast in stone: Monuments, geography and nationalism. Environment and Planning $D$ : Society and Space, 13, 51-65.

Johnson, N. C. (1999). The spectacle of memory: Ireland's remembrance of the Great War, 1919. Journal of Historical Geography, 25, 36-56.

Kusenbach, M. (2003). Street phenomenology:The go-along as ethnographic research tool. Ethnography, $4,455-485$.

Lahiri, S. (2011). Remembering the city: Translocality and the senses. Social \& Cultural Geography, 12, 855-869.

Legg, S. (2004). Memory and nostalgia. Cultural Geographies, 11, 99-107.

Legg, S. (2007). Reviewing geographies of memory/forgetting. Environment and Planning A, 39, 456-466. 
Llewellyn, M. (2004a). Designed by women and designing women: Gender, planning and the geographies of the kitchen in Britain 1917-1946. Cultural Geographies, 11, 42-60.

Llewellyn, M. (2004b). 'Urban village' or 'white house': Envisioned spaces, experienced places, and everyday life at Kensal House, London in the 1930s. Environment and Planning D: Society and Space, 22, 229-249.

Lloyd, J., \& Johnson, L. (2004). Dream stuff: The postwar home and the Australian housewife, 1940-1960. Environment and Planning D: Society and Space, 22, 251-272.

Lowenthal, D. (1985). The past is another country. Cambridge: Cambridge University Press.

Marcoux, J.-S. (2001). The refurbishment of memory. In D. Miller (Ed.), Home possessions (pp. 69-86). Oxford: Berg.

Marshall, D. (2004). Making sense of remembrance. Social \& Cultural Geography, 5, 37-54.

Meah, A. (2014a). Reconceptualizing power and gendered subjectivities in domestic cooking spaces. Progress in Human Geography, 38, 671-690.

Meah, A. (2014b, December 9-10). "Good morning video diary..." Co-producing meanings of domestic 'masculinities' using participant-generated videos. Keynote Address, Methodological Innovations Conference, creative and critical possibilities: Methods, methodologies and epistemologies, University of Plymouth, Plymouth.

Meah, A. (2014c). Still blaming the consumer? Geographies of responsibility in domestic food safety practices. Critical Public Health, 24, 88-103.

Meah, A. (Under review). Re-visioning the modern kitchen: Materialising memory, mood and agency via domestic consumption. Gastronomica.

Meah, A., \& Jackson, P. (2013). Crowded kitchens: The 'democratisation' of domesticity? Gender, Place \& Culture, 20, 578-596.

Meah, A., \& Jackson, P. (2014, August 26-29). Co-producing masculinities: Researching domestic spaces. Royal Geographical Society/Institute of British Geographers Conference, The Geographies of Co-Production, IBG London.

Meah, A., \& Watson, M. (2011). Saints and slackers: Challenging discourses about the decline of domestic cooking. Sociological Research Online, 16(2). Retrieved from http://www.socresonline.org.uk/16/2/6. html

Meah, A., \& Watson, M. (2013). Cooking up consumer anxieties about 'provenance' and 'ethics': Why it sometimes matters where foods come from in domestic provisioning. Food, Culture and Society, $16,495-512$.

Misztal, B. A. (2003). Theories of social remembering. Buckingham: Open University Press.

Murdie, R. (2002). The housing careers of polish and Somali newcomers in Toronto's rental market. Housing Studies, 17, 423-443.

Muzaini, H. (2013). Scale politics, vernacular memory and the preservation of the Green Ridge battlefield in Kampar. Malaysia. Social \& Cultural Geography, 14, 389-409.

Nora, P. (1989). Between memory and history: les lieux de mémoire [The realms of memory]. Representations, 26, 7-24.

Percival, J. (2002). Domestic spaces: Uses and meanings in the daily lives of older people. Ageing and Society, 22, 729-749.

Philo, C. (2000). More words, more worlds: Reflections on the 'cultural turn' and 'human geography'. In I. Cook, D. Crouch, S. Naylor, \& J. R. Ryan (Eds.), Cultural turns/geographical turns: Perspectives on geography (pp. 26-53). Englewood Cliffs, NJ: Prentice Hall.

Pink, S. (2004). Home truths: Gender, domestic objects and everyday life. Oxford: Berg.

Pollack, S. (2011). The rolling pin. In S. Turkle (Ed.), Evocative objects: Things we think with (pp. 224-231). Cambridge, MA:The MIT Press.

Reckwitz, A. (2002). Toward a theory of social practices: A development in culturalist theorizing. European Journal of Social Theory, 5, 243-263.

Reid, S. E. (2009). “Our kitchen is just as good": Societ responses to the American Kitchen. In R. Oldenziel \& K. Zachmann (Eds.), Cold war kitchen: Americanization, technology and European users (pp. 83-112). Cambridge, MA:The MIT Press.

Rose, G. (2003). Family photographs and domestic spacings: A case study. Transactions of the Institute of British Geographers, 28, 5-18. 
Rose-Redwood, R. S. (2008). From number to name: Symbolic capital, places of memory and the politics of street renaming in New York City. Social \& Cultural Geography, 9, 431-452.

Sarmento, J. (2009). A sweet and amnesic present: The postcolonial landscape and memory makings in Cape Verde. Social \& Cultural Geography, 10, 523-544.

Schatzki, T. (2002). The site of the social: A philosophical account of the constitution of social life and change. University Park: Pennsylvania University Press.

Seremetakis, C. N. (1996). The senses still: Perception and memory as material culture in modernity. Boulder, CO: Westview.

Shove, E., \& Pantzar, M. (2010). Understanding innovation in practice: A discussion of the production and re-production of Nordic walking. Technology Analysis and Strategic Management, 22, 447-461.

Shove, E., Pantzar, M., \& Watson, M. (2012). The dynamics of social practice: Everyday life and how it changes. London: Sage.

Shove, E., Watson, M., Hand, M., \& Ingram, J. (2007). The design of everyday life. Oxford: Berg.

Silva, E. (2000). The cook, the cooker and the gendering of the kitchen. The Sociological Review, 48, 612-628.

Steedman, C. (1986). Landscape for a Good Woman: The story of two lives. London: Virago.

Sutton, D. (2001). Remembrances of repasts: An anthropology of food and memory. Oxford: Berg.

Sutton, D. (2006). Cooking skill, the senses, and memory: The fate of practical knowledge. In E. Edwards, C. Gosden, \& R. Phillips (Eds.), Sensible objects: Colonialism, museums and material culture (pp. 87-118). Oxford: Berg.

Sutton, D. (2008a). Tradition and modernity revisited: Existential memory work on a Greek island. History \& Memory, 20, 84-105.

Sutton, D. (2008b). A tale of Easter ovens: Food and collective memory. Social Research, 75, 157-180.

Sutton, D. (2009). The mindful kitchen, the embodied cook: Tools, technology and knowledge transmission on a Greek island. Material Culture Review, 70, 63-68.

Sutton, D. (2011). Memory as a sense: A gustemological approach. Food, Culture \& Society, 14, 468-475. Sutton, D. (2014). Secrets from the Greek kitchen. Oakland: University of California Press.

Sutton, D., \& Hernandez, M. (2007). Voices in the kitchen: Cooking tools as inalienable possessions. Oral History, 35, 67-76.

Till, K. (2003). Places of memory. In J. Agnew, K. Mitchell, \& G. Toal (Eds.), A companion to political geography (pp. 289-301). Oxford: Blackwell.

Tyner, J. A., Alvarez, G. B., \& Colucci, A. R. (2012). Memory and the everyday landscape of violence in post-genocide Cambodia. Social \& Cultural Geography, 13, 853-871.

van Caudenberg, A., \& Heynen, H. (2004). The rational kitchen in the interwar period in Belgium: Discourses and realities. Home Cultures, 1, 23-50.

Warde, A. (1999). Convenience food: Space and timing. British Food Journal, 101, 518-527.

Warde, A. (2005). Consumption and theories of practice. Journal of Consumer Culture, 5, 131-153.

Watson, M., \& Meah, A. (2013). Food, waste and safety: Negotiating conflicting social anxieties into the practices of provisioning. The Sociological Review, 60, 102-120.

Watson, S., \& Wells, K. (2006). Spaces of nostalgia: The hollowing out of a London market. Social \& Cultural Geography, 6, 17-30.

Weiner, A. (1992). Inalienable possessions. Berkeley: University of California Press.

Wills, W., Meah, A., Dickinson, A., \& Short, F. (2015). 'I don't think I ever had food poisoning'. A practicebased approach to understanding foodborne disease that originates in the home. Appetite, 85 , 118-125.

Withers, C. (1996). Place, memory, monument: Memorialiating the past in contemporary Scotland. Ecumene, 3, 325-344.

Wright, P. (2009). On living in an old country. Oxford: Oxford University Press.

Zerubavel, E. (1996). Social memories: Steps to a sociology of the past. Qualitative Sociology, 19, 283-299. 